\title{
Quality Improvement of Urinalysis Results Based on Automatic Sediment Urinalysis and Urine Strip Results
}

\author{
A-Jin Lee ${ }^{1}$, Cheon \\ Gang Park ${ }^{1}$, Young- \\ Chul Bae ${ }^{2}$, and Chang- \\ Ho Jeon ${ }^{1}$ \\ ${ }^{1}$ Department of Laboratory \\ Medicine, Daegu Catholic \\ University School of \\ Medicine; ${ }^{2}$ Department of \\ Laboratory Medicine, Daegu \\ Catholic University Medical \\ Center, Daegu, Korea
}

\author{
Corresponding author: \\ Chang-Ho Jeon \\ Department of Laboratory \\ Medicine, Daegu Catholic \\ University School of Medicine, \\ 33 Duryugongwon-ro 17-gil, \\ Nam-gu, Daegu 42472, Korea \\ Tel: +82-53-650-4144 \\ Fax: +82-53-653-8672 \\ E-mail: chjeon@cu.ac.kr

\begin{abstract}
Background: Microscopic examinations are usually performed to confirm urine sediments in samples flagged in automated urinalysis. The aim of this study was to analyze the review rates and the difference in urinalysis results according to review rules.

Methods: A total of 1,408 urine samples submitted for health screening were collected. The urine chemistry test and urine sediment test were performed using EikenUS 3100 (Eiken Chemical Co. Ltd., Japan) and Sysmex UF-1000i (Sysmex Co., Japan), respectively. We assessed the rate of agreement between the 2 analyses and the kappa values for white blood cells (WBCs) and red blood cells (RBCs). Microscopic examinations were performed for all cases of discordant results between the urine strip and automated sediment analysis, some cases of concordant results, and cases of albuminuria.

Results: The review rate was $14.3 \%$. Microscopic examinations were additionally performed on 77 samples $(77 / 1,207,6.4 \%)$ including 29 and 56 samples flagged for WBCs and RBCs, respectively. Based on the results of microscopic examination, the false-positive and the false-negative results of the urine chemistry test and automatic sediment analysis were corrected. Among concordant results between two methods, a clinically significant number of false-negatives were identified ( 6 results of WBC detection [6/125, 4.8\%] and 4 of RBC detection $[4 / 145,2.8 \%])$. Among the 22 unflagged cases of albuminuria, pathologic casts were detected in 21 cases $(21 / 22,95.5 \%)$.

Conclusions: Microscopic examination based on the combined results of the two analyses improved the quality of the test.
\end{abstract}

(J Lab Med Qual Assur 2017;39:154-161)

Key Words: Urinalysis, Flow cytometry, Reagent strips, Microscopy, Quality improvement

\section{서론}

요검사는 검체 채취가 쉽고, 검사방법 또한 비교적 간단하고 신속하여 검사실에서 흔히 시행하는 검사 중의 하나로 신장이 나 요로계 질환을 진단하고 치료하는데 중요한 정보를 제공해 준다[1,2]. 요검사는 물리적 검사, 화학적 검사, 요침사검사 등 크게 세 영역으로 나눌 수 있다[1]. 물리적 검사는 색, 혼탁도, 요비중, $\mathrm{pH}$ 등을 측정한다. 화학적 검사는 요시험지봉검사가 많이 사용되며 산화, 환원반응, 발색반응 등의 화학반응을 이 용하는 검사이다. 요시험지봉검사는 산화, 환원물질, 소변 색 을 변화시키는 물질 등의 영향을 받아 위양성, 위음성 반응을
보일 수 있다[2]. 또한 검사 지연 시 요 내에서 일어나는 화학 변화, 세균에 의한 요소분해 등으로 검사결과에 영항을 끼칠 수 있다[3]. 요침사검사는 전통적으로 수기법인 현미경검사가 표준방법이지만 수작업 및 시간이 많이 요구되고 검사자 간 변 이 및 해석의 차이에 따라 표준화된 정도관리가 어렵다[4]. 임 상검사실에서 많은 양의 검체를 빠른 속도로 처리하여 업무의 효율성을 높이기 위해 요침사 현미경검사의 대체검사로 자동 요침사분석기를 도입하여 널리 사용하고 있다. 자동요침사분 석시스템에는 이미지분석을 바탕으로 하는 세포영상분석, 입 자를 흘려 세포를 분석하는 유세포분석이 이용된다. 유세포분 석법의 경우 정량적 측면에서는 우수한 것으로 알려져 있으나. 


\section{Journal of LABORATORY MEDICINE and QUALITY ASSURANCE}

\section{A-Jin Lee et al • Quality Improvement of Urinalysis Results}

재검플래그(flag)가 표시되면 이미지를 확인할 수 없어 이를 현미경검사로 확인해야 하므로 완전히 현미경검사를 대체하 기는 어렵다[5].

실제 자동요침사분석기를 사용하는 대부분의 검사실에서 는 자동요침사분석기에서 이상결과 감지 시 재검플래그 표시 된 검체에 대해서만 현미경으로 확인하는 규칙을 적용하여 현 미경으로 확인 후 결과를 보고하고 있다. 그러나 재검플래그가 없는 검체에서도 현미경으로 검사 시 병적 침사물이 나올 수 있고 요화학검사, 자동요침사검사상 백혈구, 적혈구 결과가 불 일치할 가능성이 있어 진단적 민감도가 낮아질 수 있다.

본 연구에서 저자들은 자동요침사검사 결과에서 재검표시가 없는 검체에 대하여 여러 가지 규칙으로 현미경검사 결과를 확 인하고 그렇지 않은 경우와 진단적 효용성을 관찰하였다. 재검 규칙에 따른 재검률(review rate), 결과의 차이를 분석하였다.

\section{재료 및 방법}

\section{1. 재료}

2016년 6월부터 8월까지 건강검진을 위해 방문한 성인 1,408 명의 요 검체를 대상으로 하였다. 요 검체는 수집 후 한 시간 이내의 신선한 요를 보존제 처리 없이 사용하였다.

\section{2. 요화학검사}

요화학검사 시 요시험지봉검사인 EikenUS 3100 (Eiken Chemical Co. Ltd., Tokyo, Japan) 장비를 이용하여 시행하 였다. 백혈구, 적혈구, 알부민 항목은 반정량적으로 측정하였 고 Table 1에 각각의 지표에 대한 등급체계를 나타내었다. 백 혈구는 $1+$ 이상, 적혈구는 trace 이상, 알부민은 $1+$ 이상을 양성으로 판정하였다.

\section{3. 요침사검사}

자동요침사분석기 중 유세포분석 원리를 이용하는 Sysmex UF-1000i (Sysmex Co., Kobe, Japan)를 사용하여 제조사의 지침대로 분석을 시행하였다. 병적 원주 $>1.5 / \mu \mathrm{L}$, 결정체 $>10 / \mu \mathrm{L}$, 효모 $>10 / \mu \mathrm{L}$, small round cell $>10 / \mu \mathrm{L}$ 일 경우 재 검플래그가 표시되었다.

Table 1. Grading systems of urine strip test

\begin{tabular}{lcccccc}
\hline \multicolumn{1}{c}{ Parameters } & \multicolumn{5}{c}{ Grade } \\
\hline White blood cell (negative) & $1+$ & $2+$ & $3+$ \\
Red blood cell (negative) & Trace & $1+$ & $2+$ & $3+$ & \\
Albumin (negative) & Trace & $1+$ & $2+$ & $3+$ & $4+$ \\
\hline
\end{tabular}

www.jlmqa.org J J Jab Med Qual Assur 2017;39:154-161
요침사현미경검사의 경우 요침사용 원심관에 $10 \mathrm{~mL}$ 의 요 를 분주하여 채운 다음, $400 \mathrm{~g}$ (1,470 rpm)에 5 분간 원침하여 상층을 버리고 $0.5 \mathrm{~mL}$ (20배 농축)를 남겼다. 농축액을 가볍 게 흔들어 잘 혼합한 후 침사 1 방울을 슬라이드에 떨어뜨려 염 색하지 않은 상태에서 $18 \times 18 \mathrm{~mm}$ 커버슬립을 덮고 현미경으 로 관찰하였다. 검경 시 저배율(10배)에서 원주, 상피세포, 전 체적인 배경을 관찰한 후, 고배율(400배)에서 적혈구, 백혈구, 결정체, 세균 등을 10 개 시야 이상 관찰한 다음 세포수의 평균 치를 구하여 high power field (HPF) 단위로 측정하였다. 현 미경검사는 한 명의 전문적인 지식을 지닌 임상병리사가 시행 하였다.

백혈구, 적혈구에 대한 결과는 $\mathrm{HPF}$ 단위로 측정하였고, 백 혈구, 적혈구 지표에 대한 등급체계는 Table 2 와 같다. 백혈구 는 5-9/HPF, 적혈구는 3-9/HPF를 양성으로 판정하였다.

\section{4. 요검사 결과보고 시 재검률}

자동요침사검사에서 재검플래그가 나타난 검체의 비율, 요 시험지봉검사와 자동요침사검사에서 백혈구, 적혈구에 대한 양성, 음성 결과가 불일치하면서 자동요침사검사에서 재검플 래그가 없는 검체의 요침사 현미경검사 비율을 조사하였다. 자 동요침사검사에서 알부민이 $1+$ 이상 측정되면서 자동요침사 검사에서 재검플래그가 없는 검체의 요침사 현미경검사 비율 을 조사하였다.

\section{5. 통계학적 분석}

통계학적 분석은 IBM SPSS ver. 19.0 (IBM Corp., Armonk, NY, USA)를 이용하였다. 백혈구, 적혈구 지표에 대해 요화학검사와 자동요침사검사에서의 양성, 음성 일치율 을 분석하였고, 일치하는 그룹과 불일치하는 그룹에서의 $\kappa$ 계 수를 구하였다. 현미경검사를 표준방법으로 하여 현미경검사 결과를 바탕으로 $2 \times 2$ 교차분석을 통해 위양성률, 위음성률, 민감도, 특이도를 측정하였다.

Table 2. Grading systems for urine sediment analysis

\begin{tabular}{lccccc}
\hline \multicolumn{1}{c}{ Parameters } & \multicolumn{5}{c}{ Grade } \\
\hline White blood cell (counts/HPF) & $<1$ & $1-4$ & $5-9$ & $10-29$ & $\geq 30$ \\
Red blood cell (counts/HPF) & $<1$ & $1-2$ & $3-9$ & $10-29$ & $\geq 30$ \\
\hline
\end{tabular}

Abbreviation: HPF, high power field. 


\section{Journal of LABORATORY MEDICINE and QUALITY ASSURANCE}

\section{A-Jin Lee et al • Quality Improvement of Urinalysis Results}

\section{결과}

\section{1. 재검률}

총 1,408 건 중 재검플래그가 나타난 검체는 201건(14.3\%) 이었다. 1,207 건(85.7\%)은 재검플래그가 없는 검체로 음성, 양성 불일치한 경우는 백혈구는 29 건, 적혈구는 56 건으로 현 미경검사를 시행한 건수는 총 $5.5 \%(77 / 1,408)$ 이었다. 알부민 양성인 검체 중 재검플래그가 없는 경우는 $1.6 \%(22 / 1,408)$ 로 추가로 현미경검사를 시행하였다.

\section{2. 백혈구}

요 검체의 요시험지봉검사, 자동요침사검사의 백혈구 결과 에 따라 분류했을 때 재검플래그가 없는 1,207 건 중 양성, 음 성 일치하는 경우가 1,178 건으로 $97.6 \%$ 를 차지하였고 $\kappa$ 계수 는 0.793 이었다(Table 3). 양성, 음성 불일치하는 29 건(2.4\%)
의 경우 현미경검사를 시행하였고, 검사결과 비교를 위해 음성 일치하는 1,117 건 중 105 건, 양성 일치하는 61 건 중 20 건에서 현미경검사를 추가로 실시하였다.

요시험지봉검사와 자동요침사검사의 결과가 일치하는 경 우 14 건(13.3\%)이 위음성으로 확인되었다(Table 4). 위음 성인 14 건 중 $10-29 / \mathrm{HPF}$ 가 5 건, $\geq 30 / \mathrm{HPF}$ 가 1 건으로 총 6 건(6/125, 4.8\%)이 임상적으로 유의한 위음성이었다. 불일 치하는 29 건 중 요시험지봉검사에서는 위음성이 9 건(9/29, $31.0 \%)$ 관찰되었고, 자동요침사검사에서는 위음성 8 건(8/29, $27.6 \%)$, 위양성 8 건(8/29, 27.6\%)이 확인되었다(Table 4).

\section{3. 적혈구}

요 검체의 요시험지봉검사, 자동요침사검사의 적혈구 결과 에 따라 분류했을 때 재검표시 없는 1,207 건 중 양성, 음성 일 치하는 경우가 1,151 건으로 일치율은 $95.4 \%, \kappa$ 계수는 0.789

Table 3. Classification of leukocyturia results obtained by test strip, and automatic sediment urinalysis

\begin{tabular}{|c|c|c|c|c|c|c|}
\hline \multirow{2}{*}{ Variable } & \multicolumn{5}{|c|}{ White blood cell (counts/high power field)-automatic sediment urinalysis } & \multirow{2}{*}{ Total } \\
\hline & $<1$ & $1-4$ & $5-9$ & $10-29$ & $\geq 30$ & \\
\hline \multicolumn{7}{|l|}{ Leukocyte esterase-strip } \\
\hline Negative & 828 & 290 & 9 & 3 & 4 & 1,134 \\
\hline $1+$ & 1 & 6 & 15 & 7 & 2 & 31 \\
\hline $2+$ & 2 & 3 & 5 & 11 & 3 & 24 \\
\hline $3+$ & 0 & 1 & 0 & 6 & 11 & 18 \\
\hline Total & 831 & 300 & 29 & 27 & 20 & 1,207 \\
\hline Dichotomous ${ }^{\star}$ concordance rate & \multicolumn{6}{|c|}{$97.6 \%$} \\
\hline$\kappa$ coefficient $(95 \%$ confidence interval) & \multicolumn{6}{|c|}{$0.793(0.720-0.866)$} \\
\hline
\end{tabular}

${ }^{\star}$ Agreement between the positive and negative categories.

Table 4. Results of leukocyturia ME in two groups

\begin{tabular}{|c|c|c|c|c|}
\hline \multirow{2}{*}{ Strip } & \multirow{2}{*}{$\begin{array}{l}\text { Automatic sediment urinalysis } \\
\text { (counts/HPF) }\end{array}$} & \multicolumn{2}{|c|}{ ME (counts/HPF) } & \multirow{2}{*}{ Total } \\
\hline & & $<5$ & $\geq 5$ & \\
\hline \multicolumn{5}{|l|}{ Group $(A)^{*}$} \\
\hline Negative & $<1$ or $1-4$ & 91 & 14 & 105 \\
\hline $1+, 2+, 3+$ & $\geq 5$ & 0 & 20 & 20 \\
\hline Total & & 91 & 34 & 125 \\
\hline \multicolumn{5}{|l|}{ Grooup $(\mathrm{B})^{\dagger}$} \\
\hline Negative & $\geq 5$ & 8 & 9 & 17 \\
\hline $1+, 2+, 3+$ & $<1$ or $1-4$ & 4 & 8 & 12 \\
\hline Total & & 12 & 17 & 29 \\
\hline
\end{tabular}

Abbreviations: ME, microscopic examination; HPF, high power field.

*(A) Concordant results validated by ME: $\kappa$ coefficient (95\% confidence interval) 0.675 (0.524-0.826); false negativity $13.3 \%$; false positivity $0.0 \%$; sensitivity $100 \%$; specificity $58.8 \%{ }^{\dagger}(\mathrm{B})$ Discordant results: $\kappa$ coefficient 0.129 . 


\section{Journal of LABORATORY MEDICINE and QUALITY ASSURANCE}

\section{A-Jin Lee et al • Quality Improvement of Urinalysis Results}

Table 5. Classification of hematuria results obtained by test strip, and automatic sediment urinalysis

\begin{tabular}{|c|c|c|c|c|c|c|}
\hline \multirow{2}{*}{ Variable } & \multicolumn{5}{|c|}{$\mathrm{RBC}$ (counts/high power field)-automatic sediment urinalysis } & \multirow{2}{*}{ Total } \\
\hline & $<1$ & $1-2$ & $3-9$ & $10-29$ & $\geq 30$ & \\
\hline \multicolumn{7}{|l|}{ RBC-strip } \\
\hline Negative & 704 & 323 & 31 & 9 & 1 & 1,068 \\
\hline Trace & 2 & 4 & 63 & 3 & 2 & 74 \\
\hline $1+$ & 3 & 4 & 4 & 5 & 1 & 17 \\
\hline $2+$ & 0 & 0 & 10 & 7 & 9 & 26 \\
\hline $3+$ & 0 & 2 & 0 & 10 & 10 & 22 \\
\hline Total & 709 & 333 & 108 & 34 & 23 & 1,207 \\
\hline Dichotomous ${ }^{*}$ concordance rate & \multicolumn{6}{|c|}{$95.4 \%$} \\
\hline$\kappa$ coefficient $(95 \%$ confidence interval) & \multicolumn{6}{|c|}{$0.789(0.736-0.842)$} \\
\hline
\end{tabular}

Abbreviation: RBC, red blood cell.

*Agreement between the positive and negative categories.

Table 6. Results of hematuria ME in two groups

\begin{tabular}{|c|c|c|c|c|}
\hline \multirow[b]{2}{*}{ Strip } & \multirow{2}{*}{$\begin{array}{c}\text { Automatic } \\
\text { sediment urinalysis } \\
(\text { counts/HPF })\end{array}$} & \multicolumn{2}{|c|}{ ME (counts/HPF) } & \multirow[b]{2}{*}{ Total } \\
\hline & & $<3$ & $\geq 3$ & \\
\hline \multicolumn{5}{|l|}{ Group $(\mathrm{A})^{*}$} \\
\hline Negative & $<1$ or $1-2$ & 77 & 23 & 100 \\
\hline $1+, 2+, 3+$ & $\geq 3$ & 0 & 45 & 45 \\
\hline Total & & 77 & 68 & 145 \\
\hline \multicolumn{5}{|l|}{ Group $(B)^{\dagger}$} \\
\hline Negative & $\geq 3$ & 30 & 11 & 41 \\
\hline $1+, 2+, 3+$ & $<1$ or $1-2$ & 2 & 13 & 15 \\
\hline Total & & 32 & 24 & 56 \\
\hline
\end{tabular}

Abbreviations: ME, microscopic examination; HPF, high power field; CI, confidence interval.

*(A) Concordant results validated by ME: $\kappa$ coefficient $(95 \% \mathrm{CI})$ 0.675 (0.559-0.791); false negativity $23.0 \%$; false positivity $0.0 \%$; sensitivity $100 \%$; specificity $66.2 \% .{ }^{\dagger}(\mathrm{B})$ Discordant results: $\kappa$ coefficient (95\% CI) $0.503(0.282-0.724)$.

였다(Table 5). 양성, 음성 불일치하는 56건(4.6\%)의 경우 현 미경검사를 시행하였고, 검사결과 비교를 위해 음성 일치하는 1,027 건 중 100 건, 양성 일치하는 123 건 중 45 건에서 현미경 검사를 추가로 실시하였다(Table 6).

요시험지봉검사와 자동요침사검사의 결과가 일치하는 경 우 23건(23.0\%)이 위음성으로 확인되었다(Table 6). 위음성 인 23건 중 $10-29 / \mathrm{HPF}$ 가 3건, $\geq 30 / \mathrm{HPF}$ 가 1건으로 총 4건 $(4 / 145,2.8 \%)$ 이 임상적으로 유의한 위음성이었다. 불일치하 는 56 건에 대해서 자동요침사검사에서는 위양성이 $53.6 \%$, 요 화학검사에서는 위음성이 $19.6 \%$ 로 확인되었다(Table 6).

\section{4. 알부민}

총 1,408 건의 검체 중 trace 결과를 보이는 검체가 199 건으 로 $14.1 \%$ 를 차지하였고 $1+$ 이상의 결과를 보이는 검체가 34 건으로 $2.4 \%$ 에서 알부민뇨 결과를 보였다(Table 7 ). 34건의 검체 중 22 건이 재검표시가 없어 추가로 현미경검사를 시행하 였다. 22 건 중 21 건(95.5\%)에서 하나 이상의 병적 원주가 관 찰되었다. 과립원주(granular cast)가 19건(86.4\%), 적혈구 원주가 17건(77.3\%), 광폭원주(broad cast)가 9건(40.9\%), 세포원주가 1건(4.5\%) 관찰되었다(Fig. 1).

\section{고찰}

일반적인 요검사는 요화학검사와 요침사검사를 말한다. 요 화학검사로는 요시험지봉검사가 많이 사용되며 음성이거나 참고범위를 나타내는 경우 정상뇨로 간주할 수 있다. 요침사검 사 결과는 자동요침사분석기를 사용하는 경우 대부분의 검사 실에서 장비분석결과를 보고하고 재검플래그 표시된 검체에 대해서만 현미경으로 확인하여 결과를 수정하여 보고한다. 이 런 방식으로 요검사 결과를 보고하면 시간, 비용을 절약할 수 있는 장점이 있지만 위음성, 위양성 결과의 가능성이 있다. 본 연구에서는 요시험지봉검사 결과와 자동요침사분석기의 검사 결과를 바탕으로 백혈구, 적혈구 결과가 불일치하는 경우, 알 부민뇨의 경우 현미경검사를 시행하여 결과를 확인하였다.

본연구에서는 건강검진 검체를 대상으로 하여 요유세포분 석기에서 재검표시된 비율이 201건(14.3\%)이었다. 백혈구, 적혈구에 대한 요시험지봉검사, 요침사검사가 불일치하는 경 우 현미경검사 재검은 5.5\% (77/1,408), 알부민뇨 양성이면 서 재검표시 없는 경우가 $1.6 \%(22 / 1,408)$ 로 현미경 보는 조 
Table 7. Results of albuminuria

\begin{tabular}{ccccccccc}
\hline \multirow{2}{*}{ Strip } & \multicolumn{9}{c}{ Grade } \\
\cline { 2 - 8 } & Negative & Trace & $1+$ & $2+$ & $3+$ & $4+$ & Total \\
\hline Albumin & $1,175(83.5)$ & $199(14.1)$ & $24(1.7)$ & $8(0.6)$ & $1(0.1)$ & $1(0.1)$ & 1,408 \\
\hline
\end{tabular}

Values are presented as number (\%).
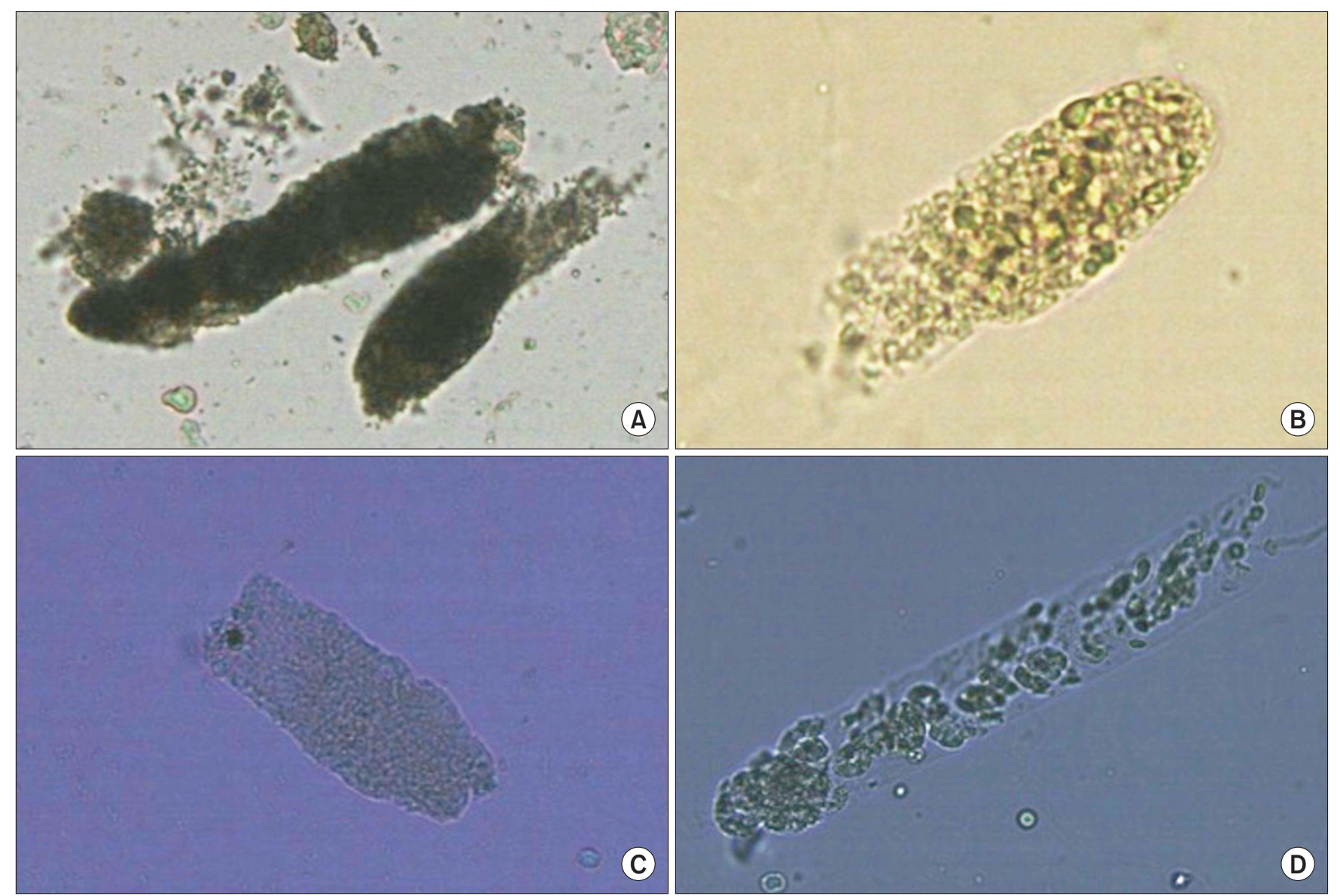

Fig. 1. Pathololgic castsidentified by microscopic examination in samples with albuminuria (×200). (A) Granular cast, (B) RBC cast, (C) broad cast, and (D) cellular cast.

건에 따라 재검률이 $21.4 \%$ 까지 증가하였다. 검진 외에 입원 환자 및 외래환자를 대상으로 하고 동일한 Sysmex UF-1000i (Sysmex Co.)를 이용한 이전 연구에서는 재검률이 재검조건 에 따라 40\%-55.3\%로 다양하였다[6]. 이번 연구와 재검률이 크게 차이가 나는 원인은 본 연구에서는 건강검진 환자만을 대 상으로 하였기 때문으로 입원환자 및 외래환자를 대상에 포함 시키면 재검률은 $21.4 \%$ 보다 높을 것으로 생각된다. 여러 가지 규칙하에 현미경 재검을 시행하는 경우 민감도는 증가하는 반 면 재검률이 높아져 검사업무의 효율성이 떨어지게 된다. 임상 검사실에서 재검률이 20\%-30\% 정도 되도록 검체 종류, 현미
경검사하는 조건 등을 조정하면 업무의 효율성을 높일 수 있을 것으로 기대된다.

요백혈구의 경우 요시험지봉검사, 자동요침사검사의 양성, 음성 일치율이 $97.6 \%(1,178 / 1,207)$ 였다. 이전 연구에서는 백혈구 일치율을 $81.18 \%-91.6 \%$ 로 다양하게 보고하였는데 이는 검체종류, 장비종류에 따른 민감도 차이에 기인하여 생 긴 것으로 보인다[6,7]. 요적혈구의 경우 요시험지봉검사, 자 동요침사검사의 양성, 음성 일치율이 $95.4 \%(1,151 / 1,207)$ 였다. UF-1000i (Sysmex Co.)와 Clinitek Atlas (Bayer Corp., Elkhart, IN, USA) 장비 간의 적혈구 결과 일치율을 


\section{Journal of LABORATORY MEDICINE and QUALITY ASSURANCE}

\section{A-Jin Lee et al • Quality Improvement of Urinalysis Results}

$77.39 \%$, 요화학검사와 침사결과가 통합되어 나오는 UX-2000 (Sysmex Co.)의 경우 일치율을 85.6\%로 보고하였다[6,7]. 백 혈구, 적혈구 모두 요시험지봉검사와 자동요침사검사의 양성, 음성이 일치하는 경우에 현미경검사와 결과 비교 시 위음성 이 관찰되었다. 현미경검사가 양성이면서 두 검사 모두 음성일 때 임상적으로 의의가 있는 위음성이 백혈구는 $4.8 \%$ (6/125), 적혈구는 $2.8 \%$ (4/145)였다. 이전 연구에서는 현미경검사를 위한 검체준비 시 원심분리과정 동안 세포가 어느 정도 손실 이 일어나 유세포분석기보다 현미경검사에서 좀 더 적은 수치 로 보고를 한 부분과는 상반되는 내용이다[6]. 검체준비과정 의 차이, 검사자 간의 차이로 인해 기인한 것으로 생각할 수 있 다. 백혈구, 적혈구 결과가 두 검사방법에서 일치하는 경우 위 음성이 관찰되어 추가적인 검사를 시행하여 확인할 필요가 있 다. 그러나 검사업무의 효율성을 고려한다면 모든 검체에 대해 서 현미경검사를 시행하기는 불가능하다. 따라서 백혈구, 적혈 구 결과가 두 검사방법에서 일치하는 경우 두 검사방법의 결과 를 바탕으로 요검사결과를 보고하면 될 것으로 생각된다.

요시험지봉검사와 자동요침사검사 결과가 불일치하는 비율 은 백혈구는 $2.4 \%$, 적혈구는 $4.6 \%$ 였다. 이러한 불일치 결과 는 간섭물질이나 특정 상황으로 인한 것으로 보인다. 이전 보 고된 불일치 비율은 백혈구는 $7.2 \%-8.4 \%$, 적혈구는 $8.4 \%-$ $11.9 \%$ 로 이번 연구에서 불일치율은 다소 낮았는데 연구대상, 장비의 차이로 인한 것으로 보여진다[7,8].

백혈구 불일치 검체의 58.6\% (17/29)가 요침사검사는 양 성, 요화학검사는 음성으로 분류되었다. 요화학검사의 경우 요 비중, 요당, 요단백, 항생제 사용 여부에 따라 위음성, 위양성 결과가 나타날 수 있다[9]. 이전 연구에서 건강검진대상자 군 에서 요중 비타민 $\mathrm{C}$ 의 양성률을 $23.1 \%$ 로 보고하였다[10]. 요 중 비타민 $\mathrm{C}$ 가 요화학검사로 요백혈구 측정 시 간섭물질로 작 용하여 위음성을 초래할 가능성도 있다. 자동요침사검사의 경 우 세포질봉합체, 트리코모나스, 변형된 상피세포 등 백혈구로 오인할 수 있는 세포를 백혈구로 분석할 경우 위양성의 결과가 나타날 수 있다.

적혈구 불일치 검체의 $73.2 \%$ (41/56)가 요화학검사는 음 성, 요침사검사는 양성으로 분류되었다. 요화학검사는 위음성 의 빈도가 높았는데, 높은 요비중, 요단백, 요중 비타민 C의 영 향으로 위음성이 나타날 수 있고, 마이오글로빈 등의 영향으로 위양성으로 나타날 수 있다[10]. 요침사검사의 경우 위양성이 30건으로 yeast 등을 장비에서 적혈구로 오인하여 내린 결과 로 볼 수 있겠다.

Sysmex UF-1000i (Sysmex Co.)의 경우 백혈구, 적혈구 측정에 대해서는 현미경검사를 대체할만한 검사능을 가지고
있다고 보고되어 왔다[11]. 하지만 요화학검사, 자동요침사검 사 결과가 $100 \%$ 일치율을 보이는 것은 아니며, 불일치하는 경 우도 있으므로 현미경검사를 완전히 대체할 수는 없다 $[5,12]$.

알부민 양성 검체의 $64.7 \%$ (22/34)에서 재검플래그가 없었 으나 추가로 현미경검사를 시행한 결과 $95.5 \%$ (21/22)에서 하나 이상의 병적 원주가 있는 것을 확인하였다. Sysmex UF$1000 \mathrm{i}$ (Sysmex Co.)의 경우 원주에 대한 민감도가 $69.81 \%$, 특이도가 $85.80 \%$ 로 다른 지표에 비해 떨어지는 한계를 보였 다[5]. 알부민뇨이면서 재검표시가 없는 경우 현미경검사로 확인한다면 원주 검출률이 증가될 것으로 기대된다.

백혈구, 적혈구가 일치하는 경우에는 현미경검사로 확인하 는 것이 실질적으로는 어려운데, 이번 연구에서 현미경검사로 검증한 결과 백혈구 $4.8 \%$, 적혈구 $2.8 \%$ 에서 임상적으로 유 의한 위음성을 확인하였다. 기존의 자동요침사분석기의 재검 플래그를 확인하는 방식 외에 추가로 요시험지봉검사와 자동 요침사검사의 결과가 불일치할 경우 재검률은 $6.4 \%$ 증가하나 현미경검사를 시행하여 위양성, 위음성 결과를 교정할 수 있었 다. 이번 연구는 건강검진대상자의 검체를 이용하여 검사를 시 행한 것으로 위양성, 위음성, 병적 원주결과에 대하여 추가적 으로 임상적인 상황을 추적할 수 없었던 점, 요화학검사와 요 침사검사 간에 동일한 등급체계를 사용하지 못한 점, 한 명의 병리사가 현미경검사를 시행한 점 등의 제한점을 가진다. 검사 실 업무의 효율과 요검사결과의 정확성을 고려했을 때 요화학 검사와 자동요침사검사 시 백혈구, 적혈구의 양성, 음성 불일 치 시, 요화학검사에서 알부민뇨 검출되면서 재검플래그가 없 는 검체에 한하여 현미경으로 침사검사를 진행하는 재검규칙 을 적용하면 요검사결과의 질을 향상시킬 수 있을 것으로 생각 된다.

\section{감사의 글}

본 연구는 대한임상검사정도관리협회의 학술연구비 지원으 로 수행되었다(2016).

\section{REFERENCES}

1. Kim KD. Urinalysis. In: Korean Society for Laboratory Medicine, editor. Laboratory medicine. 5th ed. Seoul: Panmun Education, 2014: 497-508.

2. Han TH. Urinalysis: the usefulness and limitations of urine dipstick testing. J Korean Soc Pediatr Nephrol 2013;17:42-8. 


\section{Journal of LABORATORY MEDICINE and QUALITY ASSURANCE}

\section{A-Jin Lee et al • Quality Improvement of Urinalysis Results}

3. Lee SJ. The clinical use of routine urinalysis. J Korean Soc Pediatr Nephrol 2013;17:35-41.

4. Broeren MA, Bahceci S, Vader HL, Arents NL. Screening for urinary tract infection with the Sysmex UF-1000i urine flow cytometer. J Clin Microbiol 2011;49:1025-9.

5. Lee W, Ha JS, Ryoo NH. Comparison of the Automated Cobas u 701 Urine Microscopy and UF-1000i Flow Cytometry Systems and manual microscopy in the examination of urine sediments. J Clin Lab Anal 2016;30:663-71.

6. Jiang T, Chen P, Ouyang J, Zhang S, Cai D. Urine particles analysis: performance evaluation of Sysmex UF-1000i and comparison among urine flow cytometer, dipstick, and visual microscopic examination. Scand J Clin Lab Invest 2011;71:30-7.

7. Susianti H, Lie S, Yoavita. Auto-identification of discrepancies between urine test strip and sediment results using cross check function on fully automated urine analyzer. Int Clin Pathol J 2015;1:00020.
8. Miura M, Kondo T, Mizuno M, Morikawa T. The basic analytical performance of fully automated integrated urine analyzer UX-2000 CHM unit. Sysmex J Int 2013;23:1-4.

9. Steinmetz J, Henny J, Gueguen R. Stepwise strategies in analysing haematuria and leukocyturia in screening. Clin Chem Lab Med 2006;44:464-70.

10. Lee W, Kim Y, Chang S, Lee AJ, Jeon CH. The influence of vitamin $\mathrm{C}$ on the urine dipstick tests in the clinical specimens: a multicenter study. J Clin Lab Anal 2017;31:e22080.

11. Van der Zwet WC, Hessels J, Canbolat F, Deckers MM. Evaluation of the Sysmex UF-1000i urine flow cytometer in the diagnostic work-up of suspected urinary tract infection in a Dutch general hospital. Clin Chem Lab Med 2010;48:1765-71.

12. Budak YU, Huysal K. Comparison of three automated systems for urine chemistry and sediment analysis in routine laboratory practice. Clin Lab 2011;57:47-52. 
자동요유세포분석기 결과, 요시험지봉 검사결과를 바탕으로 한 요검사결과의 질향상

\section{이아진 ${ }^{1}$ • 박천강 - 배영철 $^{2}$ - 전창호}

${ }^{1}$ 대구가톨릭대학교 의과대학 진단검사의학교실, ${ }^{2}$ 대구가톨릭대학교병원 진단검사의학과

배경: 자동요침사검사 결과보고 시 대부분의 검사실에서 재검플래그 표시된 검체에 대해서만 현미 경으로 확인하고 검사결과를 보고하는 방식을 취하고 있다. 본 연구에서는 요침사 현미경검사 재검 조건에 따른 재검률, 결과의 차이를 분석하였다.

방법: 건강검진을 시행한 성인 1,408 명의 요 검체를 대상으로 하였다. 요화학검사인 요시험지봉검 사는 EikenUS 3100 (Eiken Chemical Co. Ltd., Japan)으로 시행하였고 자동요침사분석은 Sysmex UF-1000i (Sysmex Co., Japan)로 시행하였다. 요시험지봉검사와 자동요침사검사의 백혈구, 적혈구 의 양성, 음성 일치율을 확인하였고 불일치하는 경우와 일치하는 경우 일부에서 현미경검사를 시행 하여 결과를 비교하였다. 요시험지봉검사에서 알부민뇨가 검출되면서 자동요침사검사에서 재검플 래그가 없는 검체에 대해서도 현미경검사를 시행하였다.

결과: 건강검진대상자 요 검체 재검률은 총 1,408 건 중 201 건으로 $14.3 \%$ 였다. 음성, 양성 결과가 불일치하는 경우는 백혈구 29건, 적혈구 56 건으로 총 77 건(77/1,207, 6.4\%)에 대하여 현미경검사 를 시행하였다. 현미경검사결과를 바탕으로 요화학검사, 자동요침사검사의 위양성, 위음성 결과값 을 교정할 수 있었다. 음성, 양성 일치 검체 중 백혈구 6건(6/125, 4.8\%), 적혈구 4건(4/145, 2.8\%) 이 임상적으로 유의한 위음성을 보였다. 알부민뇨 22건(22/1,207, 1.8\%)에 대하여 현미경검사를 추 가 시행하여 21건(21/22, 95.5\%)에서 병적 원주를 보고하였다.

결론: 요시험지봉 검사결과와 자동요침사분석기 검사결과를 바탕으로 현미경요침사검사를 진행하 는 규칙을 적용하면 요검사결과의 질을 향상시킬 수 있을 것으로 기대된다.

(J Lab Med Qual Assur 2017;39:154-161)

교신저자: 전창호

우)42472 대구시 남구 두류공원로 17 길 33 , 대구가톨릭대학교 의과대학 진단검사의학교실 Tel: 053)650-4144, Fax: 053)653-8672, E-mail: chjeon@cu.ac.kr 